SF 285
. L945 


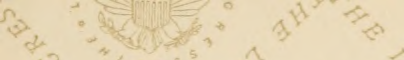 $0^{2} x^{5} s^{3}$ है,
$={ }^{2}$

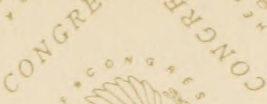

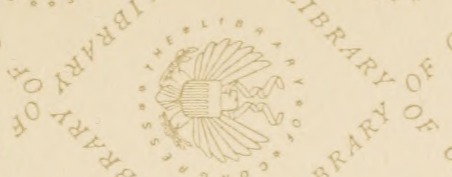

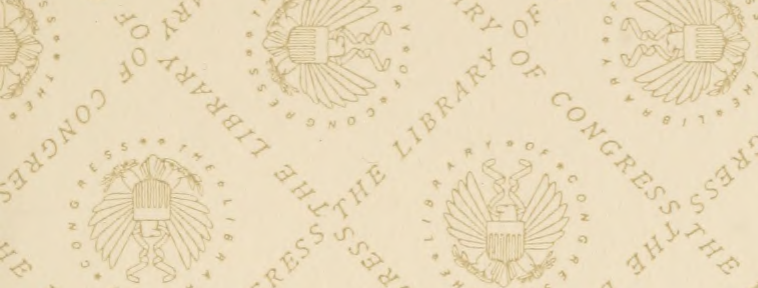

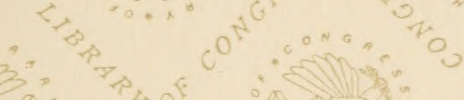

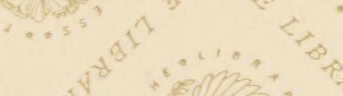

(i)

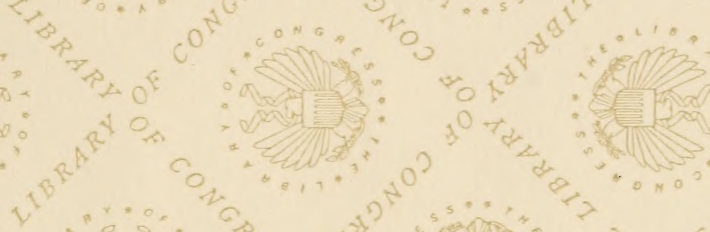

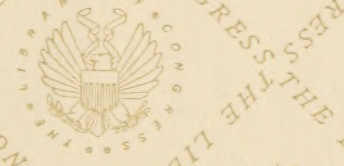

$<+$

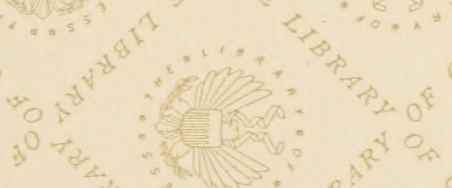

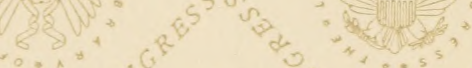

Stos

.

25:

0 ?

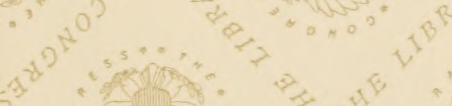

<s

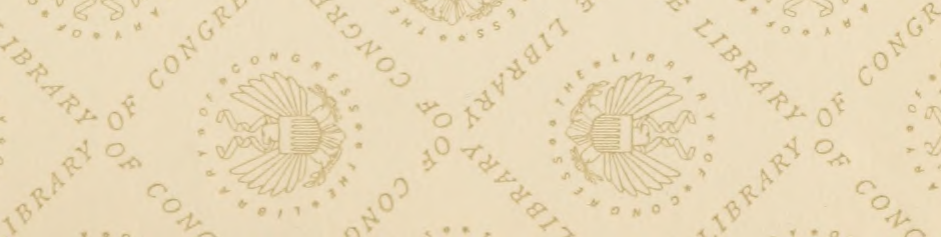








\title{
Science in the Stable;
}

\section{OR, \\ How a Horse can be Kept in Perfect Health and be Used Without Shoes,}

\author{
IN HARNESS OR UNDER THE SADDLE,
}

\section{With the Reasons Why.}

Second American Edition. Enlarged and Exemplified.

$$
\begin{gathered}
\text { JACOB R. LUDLOW, M. D., } \\
\text { Late Staff Surgeon U. S. Army. } \\
\text { Lieut.-Colonel by Brevet. }
\end{gathered}
$$

\section{EASTON, PA.:}

Press of The Eschenbach Printing House; 


$$
\begin{aligned}
& \text { S } 28^{5} \\
& 24^{5}
\end{aligned}
$$


THIS MONOGRAPH

\author{
IS \\ RESPECTFULLY DEDICATED \\ TO THE \\ SURGEON GENERAL \\ OF \\ THE UNITED STATES ARMY, \\ BY \\ THE AUTHOR.
}


Copyrighted. 


\section{PREFACE.}

\section{THIS book has not been written for the use of stable boys or grooms, but for}

the consideration of intelligent and educated persons who own, or are interested, in horses. Nor should anyone be offended, or allow himself to become prejudiced, by a mere glance at the title page. So much indeed has been written and said on this whole subject, that some sort of apology seems to be due the reader, and the writer would be loth to add anything more, did 


\section{6}

he not feel that he had something new to say, and if what has been said, should commend itself to the thoughtful, so as to lead to the crucial test of actual and thorough trial, it will be found, if courage does not lag too far behind conviction, that what has been said, is not only in some respects new, but what is of much more consequence, is demonstrably true.

As to dispensing with shoes, this may be a matter of fancy, or convenience, or economy, and is quite secondary in importance to the restoration of the animal to perfect health. But in regard to this much debated and vexed subject, it is certain that many people in various parts 
of the world do now, and have always, used their horses without shoes; and it is equally certain that not one of them can tell why they are able to do so. Others, largely in imitation of these, have attempted to dispense with shoes, and have failed. Why the first mentioned succeed, and the imitators fail, I have here endeavored to show.

$$
\text { J. R. L. }
$$

EASTON, PA., January, I897. 



\section{SCIENCE IN THE STABLE.}

NO animal so much enlists our sympathies as the horse. His strength, beauty, and docility, appeal to our finer sentiments, and his utility makes him indispensable to our comfort, and often an absolute necessity in carrying on the work of life, whether of business or pleasure. But we have all been so annoyed by the many ailments to which he is subject, and the ill condition into which he so often falls, that many people who have kept horses merely for pleasure, have been led to dispense with them entirely.

And this trouble is continually on the 
increase. As wealth and refinement advance, our horses are becoming more and more worthless. It was a vexatious experience of this kind that led me to investigate the subject, in the intervals of a somewhat busy professional life.

The value of a horse depends chiefly on his speed and endurance. If he has endurance without speed, he still has a value; if he has speed with endurance, he is very valuable; if he has endurance at speed, he is invaluable. But, if he has neither speed nor endurance, he has no value whatever.

I have frequently noticed the possessors of fine teams afraid to dash out fifteen or twenty miles of an afternoon, lest their horses should suffer. Others drive two 
or three miles at a leisurely gait, every few days, apparently to benefit the health of the horse, without regard to their own pleasure or amusement, and the only satisfaction that seems possible, is the display of a fine-looking and well-groomed team - a mere matter of pure ostentation. The horse must be constantly coddled, in the stable and out of the stable. $\mathrm{He}$ cannot stop any considerable time without being wrapped up in a warm blanket, and is always the subject of much care and solicitude.

Such a state of things was unknown a hundred years ago, at least in America. Horses were then subordinate to man, not man to the horse. A man then took no pride in his horse, unless he could do 
something. He recognized the fact that a horse was a locomotive animal, and did not rate him high unless he could go and endure. Mere beauty of form and sleekness of coat, however desirable, did not satisfy. They did not, in those days, worship "stable furniture."

Note that at that time blankets were little used,- never on saddle horses,- - and the stables were carelessly built and very open. Glazed windows in barns or stables were almost unknown.

Nowadays I frequently see horses coming from the country, blanketed to the ears, while standing in the street, with the thermometer at 60 , and the sun shining. Fully half the horses we see on the street are stiff, or more or less lame. 
Now there must be something wrong to account for all this.

Some persons have ascribed it, in rather a nebulous way, to the effects of civilization. But how does civilization act upon the horse, to produce this result? Others again lay all the blame on the horse's shoes, and the farrier is found fault with. Those who refer all this trouble to civilization, instance the horses of semi-civilized people, that are exceptionally hardy, although they receive little care, and a great deal of bad and cruel treatment. Those who put all the blame on the shoes and the farrier, cite these same people in evidence, and because they never shoe their horses, therefore, the argument is, they never get stiff or lame. 
I think I shall be able to show how civilization injures the horse, and at the same time makes shoeing necessary.

When we inquire into the natural history of the horse, we find that he is, preeminently, an out-door animal. In his wild state, he is never housed. Night and day he is in the open air. Rain or shine, cold or hot, in storms of all degrees, he has no protection. He never creeps into caves for shelter, like the bear; nor does he burrow, like the rat or beaver. $\mathrm{He}$ is not a nest builder, nor a nest seeker. He stays in the open, seeking the lee side of a hill, or thicket, perhaps, and herding together to find protection. His instincts keep him from going into thickets for cover, to avoid the attacks of carnivora. 
He seeks safety by flight, and therefore prefers the open plain. His place in nature is the temperate zone, not the torrid, as many persons seem to think. If he belonged to tropical regions, why has he been furnished with a light coat for summer, and a heavy coat for winter? The torrid zone is the home of the fruit eaters and the flesh eaters, not the grass eaters. The Arabian horse could not live in Arabia in his wild state, because the country does not furnish his natural food. Where the foods he likes best grow, and are accessible, there the horse should be found. Now his preferences, we all know, are for the grasses growing or dried, for oats among the grains and the apple among fruits. The best grasses grow in 
the colder parts of the temperate zones, and this is true of oats, and equally so of apples. In hot countries, the grasses wither and die out, or become coarse, oats degenerate, and the apple gives place to the peach and the orange and the banana, neither of which is relished by the horse. Thus we see that the foods the horse prefers, all grow in the higher latitudes of the temperate zone, or on the elevated portions of the southerly parts of this zone.

The higher latitudes, however, are subject in winter to be covered with snow for long periods, and the streams sealed up by ice, so as to prevent the animal from obtaining his necessary food; but the elevated parts or table lands of the south- 
erly portion are not subject to this condition, and while more or less cold and windy, the food supply is always accessible. When the horse was introduced by the Spaniards, soon after the discovery of America, and found his way to the highlands of Mexico and Texas, he flourished and multiplied with great rapidity, and overran the whole country, and his descendants are still with us as the well-known broncho or mustang.

The horses, however, that were left in Florida, all perished; they did not find the conditions favorable, neither the food, nor the water, nor the air. The grasses were absent, and the water abounded with alligators, that would make short work with colts, and even with horses, when 
they came to drink, and the air was full of insect life, that would give them no rest, either by day or by night; and they have left no trace, except perhaps their bones. But on these extended uplands of Mexico, stretching out for thousands of miles, he was free to roam, and in the changing seasons, to follow the growing grass, and the running water; the winds dissipated the insect life, and with the earth for his bed, and the sky for his cover, he disported himself, in the sunlight and the starlight, in the vernal rains, the thunder storms of summer, and the frosts and snowfalls of winter, and found this his typical place for living.

If we notice the things around and about us, we must see that the horse never 
suffers from cold as man suffers from it. No one has ever seen a horse with his ears frozen, nor his feet frozen, no matter how much exposed to the bitterest cold. But many of us have had personal experience of frozen ears, and I have seen many persons with frozen feet, involving the loss of the whole foot, and this, in spite of woolen stockings and warm thick shoes, and though not exposed to nearly the degree of cold that the horse resists without detriment.

When we undertake to care for an animal, the first and most essential thing is to place him as much as possible in his natural environment.

A musk-ox cannot live much below the confines of the Arctic region. When seals 
are placed in the aquarium of a museum they would die if the tank was not kept constantly supplied with ice. The common domestic rabbit will thrive in a warren; it is a burrowing animal, and needs protection from the cold, as well as a refuge from danger. The hare, or our common wild field rabbit, would die in a warren; it depends upon its fleetness for safety, and needs no protection from the cold; it must have free, fresh air, which the common domestic rabbit does not need, and could not stand. The hawk would die in a cage in a parlor, while the canary bird thrives there, and would die of cold, if exposed to conditions that are essential to the hawk. The speckled trout, the gamiest of fish, finds its place in mountain 
streams, where the water flashes in cascades or murmurs and babbles over rocky beds, thus charging itself to saturation with air. It cannot live in still ponds, where cat-fish and eels luxuriate, because this lack of freshness is not in accord with the requirements of its nature.

So it is with the horse. His nature requires an abundance of fresh air all the time, and he cannot be well, or do well, without it. He needs no protection from the cold, nor harbor of safety; but like the field rabbit, he has in his wild state, endurance at speed, and relies chiefly upon this to escape from any impending danger. We thoughtlessly compare a horse with ourselves. Man, who is a house-building animal, requiring warm clothing, artificial 
heat, and cooked food, fancies that he must place a horse in surroundings that would be comfortable to himself. So he wraps him up in a blanket, and puts him in a warm, close stable. If he has the means, and values his horse highly, he builds him a stable with matched hard wood, oiled and polished, and ceils it tight overhead. He puts in glazed windows, so as to have plenty of light, and a ventilating shaft, perhaps a foot in diameter, in the ceiling, with a closing valve, which is always shut in cold weather, and when left open, ventilates the stable about as much as taking a cork out of a bottle ventilates a bottle. He puts him knee-deep in straw, or on a good thick bed of sawdust, and then imagines his horse is happy. $\mathrm{He}$ 
gives him the best of oats, and hay, and water, and would give him fried oysters and chicken salad if the horse would eat them, simply because he likes such things himself.

Now he shuts his horse up in this way to keep him warm and comfortable. $\mathrm{He}$ believes his horse should be kept warm, because he himself needs warmth, yet he quite ignores the fact, that he does not try to keep his own apartments warm by simply closing the doors and windows, but uses stoves and heaters to keep the temperature comfortably warm, letting in fresh air from without. He knows that he would be injured if the air became foul and close. But his dominant idea being warmth, he loses sight of the fact, that in 
shutting the horse up in a close room, to keep him warm, he must of necessity poison him with foul air. The consequence of this is, that the horse rubs himself, and tears his blanket, because he is too hot, or his skin itches. He kicks against the enclosure to break an opening to let in the air; if he succeeds in breaking through, as the air flows in he becomes quiet, lies down, and goes to sleep. I have often known this to occur. Failing in this, he loses his appetite, and he gets stiff, or lame, or out of condition in some way. Then comes veterinary therapeutics, and endless contrivances, to correct what are considered his vicious habits. The viciousness, however, is in the man, not the horse. 
The trouble is, he is trying to make an out-door animal live in-doors, and that without giving him decent air to breathe. He supplies himself with a constant change of air, but seems to think that his horse needs none. What he thinks most important is warmth. He, in short, is trying to keep a hawk as he keeps a canary, or to force a field rabbit to burrow in a warren.

A horse that gets enough to eat will not be injured by the cold, nor suffer from it in any way.

Major Arthur T. Fisher, late 2 Ist Hussars, in a book published in London, I89I, referring to this subject, records many things that are well worth repeating. On page 8 , et. seq., he says: "Without the 
requisite supply of fresh air, it is impossible to maintain horses in perfect health and condition. The wilful pig-headed ignorance of grooms, in this respect, is proverbial. They are so afraid that the horses under their charge will catch cold, and their coats will 'stare,' as it is termed, that they invariably stop up every crevice and ventilator in a stable, in cold weather, thereby thinking to secure the end they have in view, whereas they are all the time but taking the most certain steps to insure the very evil they would avert. It is well known, and I may say, an undisputed fact by all those who know anything about the subject, that horses, young horses especially, on coming into stables from grass, are nearly always affected 
with throat, and often with lung ailments, in a greater or less degree; while assuming the reverse to be the case, and they are removed from stables to grass, they rarely, if ever, suffer from the change, thus proving how absolutely essential pure air is to their well-doing. Despite all that has from time to time been advanced on this subject, excepting in large establishments, a well and properly ventilated stable seems to be the exception rather than the rule, and there are many of the larger establishments, which I could name if I choose, where such details are very unduly cared for, and the ventilation is by no means what it should be, although the fittings, etc., of the stable may be very smart and lavishly carried 
out in other respects, and the horses' names painted up in gold letters, etc., and all that style of thing, I have very often in such stables been well nigh stifled with the overloaded atmosphere. $* * *$ In cavalry regiments, young horses which are purchased as remounts, are chiefly obtained in Ireland, and these come over thence, in batches, varying in number as they are required. They are packed in cattle trucks, and started on their journey, and often have to travel in severe weather, with no other protection from cold than their own coats. Yet, on their arrival, few, as a rule, seem any the worse for it, beyond fatigue and accidents, the result of kicks, etc., and it is very rarely, if ever, that they are affected with coughs and 
colds. They are nearly all brought straight from grass, yet within a few days after being placed in stables, and with every precaution taken to insure ventilation, the doors and windows of the stable being left open day and night, and but very few being placed in each stable, they nearly all suffer from coughs and colds, which generally end in strangles. During the autumn manœuvres of 1875 , I was with my own regiment, and two other cavalry regiments, encamped for some days in a place called Colony Bog, near Aldershot. It was a time to be remembered very ruefully by all who took part in them, by reason of its cheerless, wet misery; for during the ten days we were there, I can truthfully assert, that it rained almost 
incessantly, day and night, and what, even in a dry summer, was always more or less of a bog, became a lake. Until we had been there for some days, exposed to all this inclemency of the weather, the horses had not as much as even a single blanket to cover them, and yet, notwithstanding this exposure, though it is true, they were affected by the cold and wet (and it was cold and wet), in other ways, colds and coughs were unheard of. Again, at the same time, an officer of my regiment had, of necessity, to take out with him into camp - he being short of horses - an old and favorite charger, which, at the time of her going out of the stable in barracks, was suffering from a severe cold. In a few days she was quite well 
again. *** If people would but give their horses a chance of breathing the air they should breathe, and which is so essential for them, they would save themselves much anxiety and expense, consequent upon the frequent visits of the veterinary surgeon, and their horses would be more fit to look at, and more fit to go, than is but too often the case. ***

"Generally speaking, a horse does not catch cold from exposure. It is rather from the want of fresh, pure air, as I endeavored to show at the commencement of this book (as above quoted in full). With mankind, a cold generally is followed by a cough; with a horse the cough generally precedes the cold. A horse coughs, and the groom declares it to be 
nothing but a little stable cough. This description should be rendered as a hot stable cough. In such a case, it is more than probable that, there being an utter absence of proper ventilation in the stable, the impure vitiated air had irritated the mucous membrane, and so caused the cough. The irritation, unless treated promptly, spreads, and a cold is the result; the horse gets dull and restless, refuses his corn, and all the several stages of a bad cold ensue; the nostrils discharge, the poor horse is perfectly wretched, the owner is obliged to walk, and has probably to pay a veterinary surgeon a long bill, and all for the want of a little attention to proper ventilation."

The above is from an officer known as 
one of the very best and most accomplished horsemen in England.

His views of taking care of horses are, however, entirely from the standpoint of the horseman, and in other parts of his book, I notice that he does not always carry his deductions from the observed facts to their logical conclusions. In his chapter on the construction of stables, and elsewhere, he falls into the common error of thinking and acting as if the horse might be injured by too much fresh air, and therefore, in many places, gives directions about wrapping him up and regulating the amount of ventilation permissible.

Not fully appreciating the principles of physiology and natural history involved 
that should govern in this matter, he is prone to be misled by his own subjectivities, and perhaps an unconscious traditional bias, and therefore too often ignores what he sees and records as objective facts, in favor of some unscientific fancies.

I have, however, quoted his facts and observations freely, because these accord with my own experience, and as adding very valuable testimony on this subject; nor can it be said that there is anything like novelty in these views. The same thing has been enlarged upon by many writers on this subject, and for many years. Among others, the Rev. Mr. Murray, and the Hon. Geo. B. Loring, both largely experienced in stock raising, have urged the great importance of free 
ventilation, in a published work-The Perfect Horse, by William H. Murray, Boston, I873-but so far as I have observed, this insistance has always been expressed in general terms, and not in any definite manner. Now, ventilation means something, or nothing, according to the views of the individual in regard to it. Many think that airing a stable once or twice a day is the thing, others that knot holes and cracks are quite sufficient. It is exceedingly common even among those that urge the vital importance of ventilation, to close windows and doors at night, or during inclement weather. This is not my conception of the ventilation requisite for the horse. An apt, and I may say, an accidental, illu- 
36

stration of the amount of exposure to the weather, horses will bear, without injury not only, but with every sign of benefit, is given in the book above referred to. In speaking at great length and with much enthusiasm of the Justin Morgan horse-the progenitor of the family of Morgan horses of New England-he describes him as unsurpassed in beauty, strength and endurance, and especially, in the valuable power of reproducing in his offspring his own characteristics. In this book is given a letter from Solomon Steele, Esq., of Derby, Vermont, bearing date, March I2th, I856. Mr. Steele speaks of this horse from his own personal knowledge, knowing the horse well and being quite familiar with his history. 
After stating many instances of his wonderful qualities, he refers to his death. His story I will give in his own words, (page 3I7). "At twenty-nine years of age, no cause need be assigned for his death, but the ravages of time and the usual infirmities of years. But old age was not the immediate cause of his death. $\mathrm{He}$ was not stabled, but was running loose in an open yard with other horses, and received a kick from one of them in the flank. Exposed without shelter to the inclemency of a northern winter, inflammation set in, and he died. Before receiving the hurt which caused his death, he was perfectly sound and entirely free from any description of blemish. His limbs were perfectly smooth, clean, free from any 
swelling, and perfectly limber and supple. Those persons who saw him in 18 I9 and I820, describe his appearance as remarkably fresh and youthful. Age had not quenched his spirit nor damped the ardor of his temper. Years of severest labor had not sapped his vigor nor broken his constitution, his eye was still bright, his step firm and elastic." I was first inclined to italicise the words "he was not stabled," but it seemed to me, that if italics were required there, they would quite as well be required for the whole quotation. However this may be, the quotation shows, that he was kept "with other horses" out of doors, during the winter in Vermont, where zero weather is a frequent occurrence, and we may not unreasonably ask, if 
he lived out doors, exposed without shelter to all kinds of weather for twenty-nine years, and kept in such excellent condition, would shelter have saved his life when he received the hurt that resulted in his death, or, if he had been kept in stables instead of out doors for twenty-nine years, would he have been the same wonderful horse described. A severe kick in the flank would be very likely to be fatal under any circumstances, but his lifelong exposure to the weather seems not to have impaired in any way his health or strength, and may it not rather be justly credited with the maintenance of both. Nor do I think that I have here made any unfair or strained inference, in holding, if he was kept "running loose in an open yard 
with other horses" during this particular winter, when he had reached his highest reputation and value, that he was not the recipient of any greater care at any previous time, and if not stabled then, he was a stranger to a stable always. It would certainly be quite natural to give, not less, but indeed extra care to a very valuable stallion that has passed his 29th year. As stated above, one of the peculiar characteristics of this horse was his power to stamp his own individuality on his off-spring; indeed his value was not recognized until his colts were found so markedly superior. In the earlier part of his career he was sold at various times for about a hundred dollars, and at one time was hired for fifteen dollars per year to a man by the 
name of Evans, who used him in his contracts for clearing timber land-dragging off the logs by hitching him to themand doing all the hard and straining labor incident to this rough work; but the fine quality of his colts soon began to attract attention, and as he advanced in years he advanced in value, and in his old age had so much appreciated that he was finally held at five hundred dollars, a large price for the time and locality. This quality of marking his colts has its parallel in the Arabian stallions, which have been so highly esteemed in improving the breed of English and other horses. Now it will be noticed that in both cases the animals were not stabled. In the case of the Arabian horse, on account of the 
warmness of the climate; in the Morgan horse of Vermont, from carelessness, or thoughtlessness, or poverty, or all these combined. At any rate, it seems to have been the common method of keeping horses at that time in Vermont, (and in this they were right, as often happens by accident). Of course this principle here merely hinted at, applies to the mare as well as to the stallion. The animal that has the most perfect cells will predominate in the off-spring. And here we might look with much show of reason for an explanaof the disappointment many breeders have experienced in the unexpected character, or rather lack of character, in a given foal. But to resume.

It is very well known that the young 
horses that are brought from the west, for the eastern market are kept out of doors constantly, in all seasons of the year, without shelter, except perhaps, in some cases an open shed for protection against the worst storms, and they come east in excellent condition, clean limbed, supple and healthy. But very soon after their arrival they are put in warm, close stables, and they suffer from sickness, and this is called getting acclimated, when the truth is, they get sick simply because deprived of the pure air that is essential to their vigor and health. I do not deny that horses will become gradually accustomed to the closeness of a stable, but they do so at great loss to many of their best natural qualities, and at the risk of 


\section{4}

severe and often fatal sickness. I would certainly not risk a valuable horse in a close stable for a single night.

It matters not whether the air is hot, as in our summers, or cold, as in our winters: they equally enjoy it, and thrive only when the air is pure and fresh. Horses that die in snow storms on the plains, die of hunger, not from cold. Coldness, or heat, is of the smallest consequence, and although they cannot live wild where their natural foods are not always obtainable, they can be, and are, domesticated almost everywhere-in Russia and Siberia, with a winter temperature in which mercury freezes, and equally well in North Africa, from Egypt to Morocco, with their constant torrid heats, and sweltering 
winds - yet everywhere freshness is essential; and when domesticated in these tropical regions, as they have been for many thousands of years, they were exempt from being stabled, because the climate being so constantly warm, gave no excuse for the dread that they might be injured by the cold, and thus saved them from man's misguided kindness; so that here in North Africa, and also in Arabia, they enjoyed their natural condition of being constantly in the open air, and these Arabian and Moorish horses, consequently, I think, had for a long period the reputation of being the best horses in the world. We may observe this process going on at the various ranches of California at the present time, where great gain in speed 
and power has been reached, and mostly attributed to selection and breeding, with little thought as to the climate, obviating the fancied necessity for warm stables. Dryness, or dampness, counts little. A horse will be perfectly well in a damp, dewy meadow, when kept there night and day, and in all kinds of weather. If dampness were injurious, why is he so constantly seen to thrive outdoors, enveloped for long periods in a down-east-fog, or an Irish drizzle. Of course, he would be injured if kept in a close damp stable, as he would in a close dry one, or a close warm one, or a close cold one. It is not the humidity or the temperature that is at fault, but the impure deoxidized air, the unavoidable attendant upon closeness. 
We might remark here, somewhat parenthetically, that to speak of a dry, close stable with a horse in it, is simply an absurdity, the air will necessarily become saturated with moisture from the vapor of the breath and body, and the excretions of the animal. Dampness is nothing. Freshness is everything.

And now let us inquire why this freshness is so essential.

When the blood has been distributed to the various parts of the body by the arteries, and has served its purpose of nourishing the tissues, it is picked up by the venous capillaries, and carried back by the veins to the heart for redistribution. It is now forced to go through a process of purification, before re-entering the 
arteries. It comes back to the heart, purple in color, loaded with carbon waste, and the effete remains of the growth and decay of cells. Not one drop of that blood is allowed to enter the arteries again until it has passed through the lungs and been exposed freely to fresh air. Not only this, but the fluid contents of all the lymphatics, and of all the lacteals, with their loads of emulsed fat, and the new material from the stomach and liver digestion, are all mixed with the blood in the veins, on its way to the lungs. Nature emphasizes this process in a marked degree. Only a portion of the blood is sent with each pulse-beat to the kidneys for purification, and yet this purification is essential to life. But in the case of the 
lung circulation, every drop must gonew material and old material-all must receive the vivifying effect of fresh air. Here in the lungs the blood is quickly changed from purple to scarlet. The carbon wastes seize upon the oxygen of the air, and are burned up, throwing off, as the result, chiefly carbonic acid gas, just as a stove sets off carbonic acid gas by the burning of coal, the stomach furnishing the fuel, and the lungs supplying the draft - and all animal life hangs on this process. Various volatile substances are at the same time got rid of, which give more or less odor to the breath, and these, with certain organic vapors that have recently been shown to have great virulence, and the carbonic acid, are ex- 
haled by the animal with every breath. Now the result of this combustion of material by the lungs is, as in the stove, productive of heat, and here we find the great source of animal heat-that is to say, this is the chief place for the entrance of oxygen and the exit of carbonic acid, whether we speak of heat production here, for the sake of simplicity, or trace it to the ultimate cells, for scientific accuracy. Every time the animal takes in a breath of air it consumes a portion of the oxygen of the air in making heat and nerve force, and as this process goes on ten or fifteen times a minute, the air in a circumscribed space, as in a close room or stable, becomes rapidly exhausted of oxygen and overloaded with carbonic acid and other im- 
purities, and less and less fit to carry on the vital processes. New oxygen must be supplied, and the carbonic acid, etc., be blown away. If it is not supplied, as in the case of a close stable, the purple, impure venous blood, coming to the lungs, finds an inadequate supply of oxygen, and the changes so essential to life are only partially effected. The waste is not all oxydized, or sufficiently oxydized and eliminated, and consequently, we have loss of animal heat and power not only, but the retained tissue waste is carried back by the arteries to the tissues, in spite of nature's care to prevent it, and acts as a poison to the whole body.

Nature, truly, seems to set up certain vicarious actions to partially remedy the 
defect, but is handicapped in its efforts. It sets the kidneys to do extra work, and the urine becomes loaded, and the kidneys and bladder may suffer damage for trying to do what should have been done in the lungs. The skin takes on extra duty, and we have excessive sweating; and various scaly, itching, and unsightly eruptions make their appearance.

The retained and poisonous tissue wastes affect the muscles, and stiffness of the shoulder manifests itself, or weakness of the back, or muscular defect somewhere. The hoofs become slowly impaired and lose their toughness, and become brittle and weak. The nervous system suffers, and the animal loses vivacity, vigor, and endurance. Touching 
the brain, you have the temporary delirium, known as "blind staggers." Affecting the co-ordinating centres, you have stumbling and "string-halt." Settling upon the digestive tract, "crib biting," and "wind sucking" and colic appear. Affecting the ligamentous and bony parts, "spavin" and "splint" result, and in the eye all those changes of nutrition which result in partial or complete blindness. So, too, the lack of oxygen in the blood causes irritation of the kidneys and bladder, because the waste excreted by them is not sufficiently oxydized, and consequently is deficient in solubility. This often causes difficult and painful urination, to the extent sometimes of complete retention and so-called "bladder "colic." 
In mares, the irritating quality of the urine shows itself by a frequent and disagreeable ejaculatory micturition, generally attributed to the animal being "in heat," when it is really suffering from irritability and soreness of the urethra and neck of the bladder, from this gritty or loaded condition of the urine. I think it is not too much to say that about 98 per cent. of the disabilities to which horses are at present liable are traceable to deficient oxidation of the tissues, caused by withholding the supply of fresh air which their nature requires. This is fully corroborated by the reports of both English and French authorities. Rossignol states as to the French cavalry horses, "that previotis to 1836 the mortality was as 
high as a hundred and ninety-seven per thousand *** but in 1866 this was reduced by improved ventilation to twenty-seven and a half per thousand." "In the Italian war of I859, M. Moulin, the chief veterinary surgeon, kept ten thousand horses many months in barracks open to the external air, in place of closed stables. Scarcely any horses were sick." Wilkinson (English) says, "the annual mortality of cavalry horses-which was formerly very great-is now reduced to twenty per thousand, of which one-half is from accidents and incurable diseases." So that the estimate I have given is rather under the truth, and instead of ninetyeight, I might have said ninety-nine per cent. without the least exaggeration. 


\section{6}

When a horse is violently exercised, all the tissue changes are accelerated. The heart beats quicker. The breathing is hurried. Why? Because there is more waste tissue to be disposed of. The blood rushes to the lungs for more oxygen, and the lungs hurry the breathing to meet the demand.

If the horse is in good condition, the blood well oxydized, and the cells of the various tissues thoroughly healthy, as in a horse that has been liberally supplied with fresh air, the blood rapidly takes up the oxygen, the extra waste caused by the exercise is thrown off and exhaled as carbonic acid gas, and becomes harmless. These increased tissue changes evolve not only nerve energy or force, but extra 
heat is generated by the accelerated combustion, and of course warms up the body, and, as the organism would be seriously damaged if the temperature rose much above 99 degrees, the automatic mechanism that regulates the temperature causes an increased action of the sweat glands of the skin, and the coat of the animal becomes wet with perspiration, or merely moistened, in proportion to the violence of the exercise and the state of the weather; and the evaporation of this perspiration cools down the body and keeps it at the normal temperature, and no harm to the animal results.

But if the horse has been deprived of his full allowance of air by a period of close stabling, and his blood is only par- 
58

tially oxydized when this fresh rush of tissue waste is poured into the blood, the lungs become congested, because they are behind their work, and cannot dispose of the extra load put upon them, and it is not an uncommon occurrence for such horses to die from this lung congestion in a short time, or from a resultant pneumonia, and if they recover at all, they are a long time in bad condition, to the great loss and inconvenience of the owner.

I have here given the common beliefs as to the cause of death in these cases, rather than my own impressions. I believe these horses die from the effect of certain blood poisons, produced or retained in the blood because of the lack of oxygen, and among them we would 
certainly find a dangerous excess of carbonic acid gas, and possibly, the generation of more or less carbon monoxidewhich is about as fatal to animal life as prussic acid - acting according to Ferrier "by paralyzing the blood corpuscles, as Bernard expresses it, and rendering them unable to take up oxygen. Hence, internal respiration is prevented, and death ensues from asphyxia." This principle of autoinfection, which has arrested the attention of the medical profession of late years, is well illustrated in these cases.

Even if the horse escapes these immediate dangers, the increased waste, chiefly of the muscles, caused by the severe exercise, increases the demand for oxygen, 
and if he is taken back to his accustomed close stable, where the supply of oxygen is insufficient, his embarrassment is very much aggravated, and the blood becomes more loaded than before with these retained materials, which, floating in the blood current, act, as I said before, as poisons to the tissues, especially to the muscles, which are supplied with an enormous amount of blood, and therefore are much more exposed to the action of these poisons; and the muscles, being the motive power of the animal,- - his electric motors, so to speak, - are among the first of the organs to show that they suffer; and it is after violent and continued exercise that, in horses kept as described, we often have an acute or sudden attack of 
muscular breakdown, commonly called "founder," " chest founder," etc.

Now it can be seen readily, I think, that a horse in the condition above described would have had a much better chance to recover if, instead of being closely stabled after the exercise, he had been left for hours in the open air. That might have given him the necessary oxygen to dispose of his extra load of waste.

If, however, the amount of poison in the blood is not sufficient to produce the sudden or explosive action just spoken of, - and these extreme results are oftenest seen in horses not constantly used,-if the animal is worked about every day, and closely confined when at rest, nature seems gradually to get accustomed $t_{O}$ 
these morbid conditions, and you have a slow, progressive paresis, or atrophy of some, or we might say many, of the voluntary muscles, going under the general name among stablemen of "sweeny," and the horse slowly becomes stiff and awkward in some of his movements, and finally shrunken, ungainly, ewe-necked, swaybacked, or in some way distorted.

He loses his free and expansive muscular movements as well as his graceful lines, because his muscles have lost their elasticity, and power, and plumpness ; and then you have a miserable-looking, clumsy and deformed animal, called in some places "an old plug," or "skate," or the like; such as you sometimes see in front of an ash or garbage cart. Fortunately, very 
many of these horses die long before reaching this stage of degeneration.

In speaking of the automatic action of the heat regulators, alluded to before, it might be as well to digress a little, and inquire as to the propriety of warmly blanketing horses after severe exercise. What is the condition of a healty animal that comes in reeking with sweat? It is certain that his body has been extremely heated, as shown by his sweating. What will happen if he is allowed to stand in the open air? The horse is still panting, which shows that he is hurrying the combustion of his tissue; the heart is beating quickly, to send the blood quickly to the lungs, to have its burden of waste products disposed of, and 
64

consequently, he is thereby still making an additional amount of heat. If allowed to stand in the open air, the extra heat being generated will quickly dry the coat, and as the heat subsides, the hair will rise slowly, if the air is cool or cold, and thus prevent the too rapid dissipation of the heat, and the animal resumes his condition as before.

But covering a horse with a blanket when hot and sweating checks the escape of the vapor driven off by the heat of the body, and thus retards the drying process and the retention of the moisture, and the dampness of the blanket will, if the weather is cold, cause shivering as the heat of the body gradually subsides; and it also partly prevents the rising of the coat, 
thus thwarting the very processes of nature set up for the protection of the animal.

What is true of the ordinary blanket is more than true of the gum-blanket. The gum-blanket is an abomination. It may possibly sometimes protect the harness, but always hurts the horse.

The self-regulating heat-apparatus will bear some consideration, and it may as well be spoken of in this connection.

When the air is mild the coat will remain smooth. If the air becomes cooler, the coat will rise just in proportion to the change of temperature, and becomes loose and fluffy in the cold. This, practically, thickens the coat and makes it warmer. If, however, a horse suffers from cold 
which the rising of the coat is not adequate to relieve, another automatic operation is set to work, and he begins to shiver; that is, the muscles that move the skin, and whose common use is to shake off insects that annoy the animal, are set in motion all over the body, and this adds to the heat production by increasing the waste of tissue, just as the exercise of the muscles of locomotion have that effect when the animal is at work. A healthy horse will rarely, if ever, shiver in the open air. Shivering generally indicates a sick horse or one that has been or is being semi-suffocated by close stabling.

Now, if the air becomes warmer, or the horse is exercised, the coat will slowly 
fa11. Thus, when it is necessary to keep in and preserve the heat, the coat rises, and practically becomes thicker, just enough to preserve the proper equilibrium of temperature, not allowing it to fall much below 99 degrees; and, when it is necessary to increase the heat dissipation, the coat falls, or slowly becomes moist, just enough to control the temperature from rising above 99 degrees.

In a healthy horse, in summer, a reverse action may be observed. If the animal is standing or moving slowly in the hot sun, the hair will be seen to rise, to shut off the effect of the sun and to preserve the skin from being too much heated. Here the coat is practically thickened, to keep the sun from injuring the skin - to keep 
68

the heat out-just as in winter the coat rises to keep the heat in.

I have often noticed the rising of the summer coat in the hot sunshine. It puts on the appearance of cut velvet. The farmers say the horse raises his coat to keep off the flies. This, however, may not be noticeable in horses closely stabled, because their skins rarely become dry enough to produce it.

If, however, when the summer coat is up against the sun's rays, you quicken his motion, and consequently his internal fires, down will go his coat, and moisture will begin to appear. He is now cooling himself, by the process of evaporation, just as he does with his winter coat, in cold weather, when exercised. 
69

We have been considering the condition of a horse just brought in after severe exercise. Shall he be closely stabled and blanketed? I have tried to show that this is not good practice. Scarcely any one would think of throwing him a mess of grain immediately. Yet there is a physiological reason for this, which it might be well to consider. When a horse is brought in hot and sweating, we have shown that this condition is owing to the rapid combustion of his tissue. He has now all he wants to do in replenishing his store of oxygen and blowing out his surplus carbonic acid until he cools off by the evaporation of the wetting Nature has given him and the gradual subsidence of his internal fires. If we now give him a 
mess of grain, we are adding fresh fuel to the fires, as the newly digested grain is poured into the blood, thus seriously increasing the already urgent demand for oxygen.

These views are perfectly in accordance with the ordinary practice of horsemen in this particular. It should not go unnoticed that a horse that has been overdriven, and is very much exhausted by excessive work, will not eat, even when his food is placed before him. Thus his nature protects him from injuring himself, by taking away his desire for food at the time when to eat would be hurtful.

For obvious reasons it might be inferred that feeding too early in these cases would be more likely to be injurious in hot than 
in cold weather and in a closed stable than outdoors.

Of course, the diversion of blood from the digestive organs to the muscles is worth considering, but this would apply to work after feeding as well as to feeding after work, and the effect would be chiefly referable to the stomach and digestive tract.

Whether the withholding of water is of so much importance, I am not prepared to say. There seems to be some difference of opinion on that subject. It is probably safer to err on the side of care. Yet the loss of water, by the sweating of the animal, would seem to indicate that the loss should be made good, and his thirst will always induce him to drink. If the water 
was warmed, it could not do harm, and might be of great advantage, by increasing the fluidity of the blood. The practice in regard to this seems to vary in different localities, and experience ought to settle the question. That of our "cowboys" would be of value on this point. It is a common practice, however, of many owners of horses in the South and West to ride their horses until they are reeking with sweat, let them drink when they please, and leave them in the open air, without protection of any kind. But these horses, if stabled at all, are kept in stables about as fresh as outdoors.

This question can only be settled satisfactorily by experience with horses that have not been closely confined in 
stables, because horses that have been deprived of their full allowance of air for any considerable time are in a pathological condition, and what would obtain with them could not be predicated of horses in perfect health. And this will apply to all our past experiences with horses. Horsemen, and veterinarians, and farriers, and grooms, all alike, have learned, personally, or by tradition, everything they know about horses, from the taking care only of those that are all really more or less out of condition from partial suffocation by close confinement; and, because it has been noticed that such animals often become stiffened or lame, or get a cough, or a colic, after drinking or feeding, or exposures to drafts of air, when heated by 


\section{4}

exercise, they have formulated a set of rules which may very well apply to animals so kept, but would have no application whatever to the same animals under normal conditions; and thus we hear of grain founder, and water founder, and air founder, as the results of such and such alleged causes, all occurring, however, in horses that have been very carefully kept; while at the same time men who are deemed careless, and let their horses run wild, and take their chances, are little, if at all, troubled in this way. This is generally explained as a matter of accident, or passed over as a "fool for luck" case ; and really these reckless fellows who are always in luck could not give any better explanation themselves. So that we have 
to begin at the very beginning and slowly learn what management the horse requires when kept as nature keeps him-in the open or its equivalent,-and I think it will be very soon apparent that our past accumulated knowledge is no knowledge at all, because in forming opinions as to the causes and cures and preventives of his various ailments, we have overlooked by far the most important factor of all, namely, the taking him out of his natural environment and forcing him to live as nature never intended him to live. It is said that Lord Palmerston once remarked that "The best thing for the inside of a man is the outside of a horse." However this may be as a matter of personal experience, it is a fact, easily demonstrated, 
that the best thing for the inside of a horse is the outside of a stable.

I have spoken of the automatic arrangement for regulating and maintaining a normal temperature existing in a healthy horse. When horses have been too closely stabled the delicacy of this mechanism is impaired. Their skins seem to be unnaturally wet, and the perspiration oozes out on the slightest exertion, and when in their summer coats a very short drive will give them the appearance of being varnished. This is looked upon by many as a marvel of skillful grooming. It is simply a pathological condition-a sort of colliquative sweat. This condition, indeed, seems very closely allied to the excessive sweating that occurs in phthisis- 
consumption of the lungs - in man, where from the diseased and disorganized state of the lungs the entrance and absorption of oxygen and discharge of carbonic acid is necessarily interfered with. When in winter coat it causes so much inconvenience that it has induced a practice, now quite general, of clipping or singeing-removing the winter coat entirely, - and this seems to be necessary, and even advantageous, under these circumstances.

But this whole trouble - this inordinate sweating, this "leaky skin"-is produced by the poisonous action of the retained tissue waste, caused by the deprivation of oxygen acting, probably, through the vasomotor nerves, deranging the delicate adjustments so essential to health. 
It might not be out of place to mention, also, that a close hot stable will cause a horse to lose his winter coat prematurely, and he will begin to abort his hair sometimes as early as the middle of January, and by constant rubbing, it will be pretty well off by the first of March, and he will be very imperfectly protected from the subsequent cold weather, and his summer coat will not be so fine as it otherwise would be.

In this climate the coat should not begin to loosen much before the 21st of March, and he will not be in complete summer dress until near the Ioth of June. He will generally begin to shed pretty freely by the Ist of April, and this will go on, subject to checks by cold snaps, 
the coat becoming gradually lighter, until its disappearance in the early summer. This seems, however, to be influenced considerably by the grooming and the feeding.

The same close stabling causes the growth of the so-called "cat-hairs" in the coat, some of the hair follicles becoming hypertrophied by the constant irritation of the skin. These never show themselves in a perfectly fresh stable.

I wish here to call attention to a fact which is a matter of common observation. It has often been noticed that horses will shiver in a close stable in cold weather, especially in the morning after the animals have been shut up all night, gradually abstracting the oxygen from the air and replac- 
80

ing it with carbonic acid. The thing that naturally suggests itself to the keeper is a blanket, and I have known at least three blankets to be applied, and the animal would still shiver. The next thing that occurs to the groom is to shut out the cold and make the animal comfortable by stopping, with the most religious care and solicitude, every crack and opening that might possibly admit any cold air from without. Now, paradoxical as it may at first appear, this shivering is produced by the closeness of the stable, and if the animal is taken outdoors, or the stable sufficiently opened, this shivering will in a short time cease. It will be remembered, as has been stated before, that the great source of animal heat is the oxidation of 
the tissues. If the animal is kept in an enclosure where the oxygen supply is deficient, he cannot burn his fuel well, and therefore cannot keep up his heat; he is cooling down too much because his fires are burning low. If you cut off the supply of material to be burned, as in starving animals, they will shiver too. It makes no difference, as to the production of animal heat, whether you give insufficient food or insufficient oxygen. The result as to heat production will be the same, just as in a stove you get similar results from using little fuel or shutting off the draft. In other words, you get the same objective symptom of shivering, whether you starve the animal by withholding food or withholding oxygen. 
And we should not permit ourselves to forget our elementary physics so far as to lose sight of the fact that a cubic foot of air at zero contains much more oxygen than a cubic foot of warm air. Thus nature makes up for the low temperature by an increase of the heat-producing oxygen, just in proportion to the needs of the animal, and any attempt to warm the breathing air artificially-worst of all, by closing doors and windows - is plainly doing what is most desirable to avoid. We lose the benefits of the fresh cold air, which invigorates not only or chiefly because of its coldness, but because it is rich in oxygen as a consequence of its being cold.

Air is dilated one part in $49 \mathrm{I}$ of its volume for every degree of Fahrenheit. 
83

Estimating the amount of oxygen in $49 \mathrm{I}$ cubic inches of air at $100^{\circ}$ - extreme summer temperature,- the same amount will be represented in 39I cubic inches at zero. Thus an animal breathing the air of cold winter weather gets about twenty per cent. more oxygen than during the extreme heats of summer. And it is a fact worthy of notice that a horse out of condition in any way will improve much more rapidly in a given time exposed to the cold fresh air of winter than in warm weather, for the plain reason that the increased supply of oxygen in the condensed cold air quickens all the tissue changes; that is, builds up and pulls down the materials of the body faster - in other words, expedites the process of growth and decay, which is 
84

the very essence of vitality. The experience of Lieutenant Peary on the ice-cap of Greenland plainly points in the same direction. Encountering a violent blizzard at the outset of the expedition, snow huts, or "igloos," were built, in which the party "crept" for protection from the violence of the winds and the painful cutting of the ice-sand "into the faces of the advancing column," which they found almost unendurable, but they suffered so much more from cold during their confinement in these huts that they were glad to abandon them. "The experience with igloos had proved so disagreeable, they were found so cold and occupied so much time in building, that on the later marches they were entirely dispensed with." (In Arc- 


\section{5}

tic Seas, Philadelphia, Rufus C. Hartranft, I892, page 378). Now here the increased warmth of the shelter was more than counterbalanced by the unavoidable restriction of the oxygen-supply. If the party had constructed a hut, with the leeside open, or even a perpendicular wall of snow, they might have found some comfort on its lee side, without the necessary loss of heat production from the diminished amount of available oxygen incident to living in a tight lut; but in these igloos they felt the same discomfort that a shivering horse feels in a close cold stable, and from the same cause. I will add right here that nothing more clearly or certainly gauges the sufficient freshness of a stable than the fact that the horses 
do not shiver nor even raise their coats in the coldest and windiest weather. Whenever shivering occurs, it is an absolute certainty that the stable is too closely shut instead of being too open. This is one thing I have seen verified by actual experiment so often as to exclude the possibility of error.

When food supply is in excess, especially if the amount of fresh air is limited, nature has a fashion of relieving the blood of the excess of carbonaceous material by storing it up as fat, and especially as subcutaneous fat, and the animal, instead of burning the excess or excreting it in any way, packs it up for future use, and in this way renders it harmless.

Now this is all very well for a prize ox, 
intended for the shambles or exhibition at a county fair; but excess of fat is an encumbrance to the horse, by its added weight not only, but a heavy layer of fat under the skin, by its non-conducting properties, keeps in the animal heat, and in one that is driven rapidly is a serious impediment, and requires a more profuse perspiration to preserve the equilibrium of temperature. All practical horsemen know this, and avoid driving a very fat animal at a rapid rate. Horses used for racing are "trained down" by active exercise to prevent this accumulation, and instead of fatness we have force. Some persons take great pride in having their horses look fat, and smooth, and plump; and this is all very well for those who 
88

like it and are satisfied with a three or four-mile-an-hour gait, but it will not do for rapid travelling. It will answer for a mill horse or a brewer's team, but not for a roadster, or a trotter, or a hunter.

Nevertheless it is well to discriminate between plumpness, the effect of excess of fat, and plumpness produced chiefly by nicely rounded and fully developed muscles. The latter is always desirable, and gives beauty, strength and power, while fatness gives neither, a fact that some people seem to have overlooked.

If the food supply instead of being in excess, is diminished below the requirements of the animal, what follows? Nature then begins to draw upon the laid-up-fat to help in maintaining force and heat, and 
89

the animal soon loses its plumpness and roundness of form, and becomes thin and angular, showing its ribs and bony framework generally. When the fat is largely consumed the muscular tissue is - directly or indirectly - slowly sacrificed in keeping up heat and power, and consequently, movement and locomotion become gradually enfeebled, and he is spoken of as thin and weak; if running wild, and he can get nothing else to eat, he will have recourse to the bark and limbs of trees; if stabled, he will eat up his manger. He makes a struggle for life, and to preserve it, uses up every available material except his brain and nervous system; these must be kept in reserve to the very last. If he is now exposed to severe cold, he will very 
90

likely die. He has been getting enough oxygen, but his coal-bins are about empty - he has burnt up much of his furniture, and his fires are in danger of going out for want of fuel. You may call this freezing or starving, just as you please. But starvation is dying from cold.

I think I have now shown sufficiently how civilization, or at least our civilization, causes the infirm condition of our horses, and how it necessitates the use of shoes, because horses kept as our horses are commonly kept cannot be driven without shoes. The hoof will not get used to it, and every trial of this kind will result in failure.

But if we consider the subject carefully, we must see that all peoples who use their 
horses without shoes have one thing in common, and only one thing, and it is this: that none of them have stables.

There is no exception to this rule. Therefore, if we wish to dispense with -shoes, we must dispense with stables. But it is next to impossible to dispense with stables - absolutely so in cities and towns. A stable, then, must be looked upon as a necessary evil, and our aim should be to minimize the evil, or, if possible, eliminate it entirely. The evil is in the restricted supply of oxygen, and this can only be corrected by making the stable as fresh as the pasture ground or the prairie. This simple procedure is the key to the heretofore unexplained puzzle, why some persons find shoeing necessary and others do not. 
It goes without saying, that this freshness must be kept up at night as well as in the day - at all times - in all seasons - in all kinds of weather. This may seem like tiresome iteration, but it is so essential to success that it cannot be too much dwelt upon, for by this means only can we practically restore to our captive animal his natural environment and bring back to him the conditions of perfect health and perfect hoofs.

I have been experimenting in this way for the last five years, and I find that a stable can be built that will give absolutely the same results as are gotten by dispensing with them altogether, and the horses kept in such stables can be used without shoes, either in harness or under the saddle. 
93

I have driven my own gig horse without shoes for two years - winter, spring, and summer,-and my saddle horse has not been shod in four years, although ridden from March to December, over macadam roads, boulder stone pavement, vitrified brick, and country roads, and his hoofs are perfect. Everyone knows that saddle work is harder on the feet than work in harness, and my usual weight is I7O pounds. His feet wear true and smooth, and his hind feet keep their points, are nicely oval-we may say spoon-shaped,- his front feet are slightly worn at the toes, rounded a little, just as an iron shoe wears at this point. The farriers and veterinarians who have seen him and known how much and how long 
94

I have used him without shoes, consider the result as very wonderful, and I will admit that the result has been something of a surprise to myself.

I do not wish to assert, however, that a horse can certainly be driven thirty miles a day, every day in the week, over hard macadam roads, without shoes. This could only be known by trial. I am satisfied, from what I have seen, that horses moderately used, and farm-horses and those employed on country roads or on the race track, can be so used with great advantage.

But if shoes are required in some cases, they can be fastened to a good tough hoof much more readily and securely, and with fewer nails and less depth of penetration, than on a common hoof. 
It is hardly necessary to recount the advantages of this method. Besides the expense and trouble of sending a horse to the shop to have him shod, at least a dozen times a year, he, of course, never "cuts" himself - he is in no danger of "calking" himself, an accident so common in winter when sharp-shod; he is not subject to "capped elbow," he never "balls" in snow, and he does not slip on the ice. This I know from personal observation. Neither does he slip on wet and slippery asphalt or vitrified brick, or any of the smooth-faced pavements of cities, which have been so much complained of by horsemen, as dangerous on account of their extreme slipperiness in wet weather. 


\section{6}

The additional weight of the shoe from a half pound to two pounds on each foot-is also a matter of very considerable importance in encumbering and retarding the movements of the animal. This has been calculated and estimated, by persons mathematically inclined, and may be found in detail in various veterinary books.

I have carefully compared the growth of the hoof of an animal, stabled as described, with that of horses brought from city stables and turned to pasture without shelter for a course of four or five months. If one will observe the effect on the nutrition of the hoof that occurs in a horse that has long been closely stabled, and is then turned outdoors to pasture, he will see that this effect can easily be recog- 
nized by the naked eye. The hoof grows - I am speaking now of the outer shell about a quarter of an inch per month, so that in three months three-quarters of an inch of new hoof will have been formed. It is so different that its growth can be followed by the eye, month by month. Its grain is finer, its surface smoother, it is much bluer in color, and it is also a little smaller in diameter - about one-sixteenth of an inch on each side. This can be followed in a pasture field, for about five months, to the closing of the pasture season, and is accounted for by the farmers as due to the dampness of the ground and the dew on the pasture. But I have followed it through the entire year in a stable that is absolutely fresh, and 
98

have compared the hoofs grown in such a stable with those grown in a pasture field, and they are absolutely identical. But when the horses are taken from the pasture and put back in their accustomed close stable, the reverse change will be observed. If the hoof is washed so as to expose its surface, the changes in the growth of the hoof will be quite as distinct. Now it will be coarser, rougher, and less blue, or rather grayish, and a little larger. Five months in open pasture will give about one inch and a quarter. Seven months of close stabling will give one inch and three-quarters, making about three inches as the length of the hoof. It is a little more than this, but the difference is here practically of no 
consequence. Now the last inch and three-quarters, of course, is grown last, and therefore that will be above, and the inch and a quarter of good hoof, having grown in the pasture the summer before, will be below, and that you will find if the foot is examined in the spring. I have observed it in scores of farmers' horses in the spring, when there happened to be snow on the ground, which washed the feet in coming to town and exposed the grain of the hoof to view as they were standing on the street. It was the great difference in the hoof grown in the open air from the hoof grown in an ordinary stable that attracted my attention, and when I found I could preserve this openair character, and continue its growth 
during the whole year, I determined to test its strength practically, and the result I have already stated.

If you divide the time necessary to grow a new hoof from the matrix (coronet) to the free edge, which requires about twelve months, and keep the animal four months in the open air, and then four months in a closed stable, and then again four months in the open air, an examination of the hoof then will show three bands of growth, easily distinguishable. At the free edge about one inch of good healthy strong hoof, the first grown of the series, then about one inch of rough, weak hoof, formed in the second four months, while in the closed stable, then about one inch of good hoof, extending to the matrix, 
and grown during the time of the last four months, in the open. I have occasionally observed such hoofs. In observing these changes in the character of the hoof, it is of course necessary that in alternating between close stabling and open air, the transition should be sharp and decisive, otherwise the result will not be clearly defined. It is very well marked in the case of farmers who shut their horses up very closely in banked-stables during the winter, using them but little, and keeping them outdoors most of the time in the warmer months. If the alternations are irregular, or not pronounced, the result will be correspondingly confused and obscure.

This change of nutrition extends from 
what we can see to what we cannot see. It would scarcely be reasonable to suppose that one part of the hoof - the outer shell, for instance-would undergo a change of nutrition so marked and observable without corresponding change in other parts of the hoof. The sole would necessarily be effected in the same manner and degree. I had an accidental illustration of this in my own horse while driving one day in February, when the weather was cold, and with a few inches of snow on the ground. I noticed that he suddenly limped for a few paces. As this had not occurred before, it attracted my attention. It passed off immediately, however, and I thought no more of it, as he travelled over the frozen streets without showing any dis- 
comfort, and trotted into the carriagehouse, with its hard plank floor, without any sign of inconvenience. On accidentally taking up his front foot, as I was in the habit of doing occasionally, to my surprise I found a ten-penny cut nail which had entered the cleft of the frog, and was bent over and lying flat on the sole. On taking hold of it, I found it quite loose, but could not get it out, and the hostler coming up, seized it with pincers and pulled it out, tearing the frog somewhat in doing so. On examining the nail, the end was found bent around in the form of a hook, which accounted for the difficulty in pulling it out, and likewise, for the tearing of the frog. Now this nail, which was a new one, must have been straight 
when it entered the frog, and could only have been bent by encountering the hard and tough laminæ of the sole. When the point first impinged against the sole, as it was driven in by the blow of the foot, it was felt, and caused lameness for a few steps, but being deflected, and its point bent round, it could go no further, and the subsequent blows of the foot flattened it against the sole, and it caused no more inconvenience. The horse showed no lameness afterward, and I doubt if it would have caused any trouble had it remained.

I have known a horse to have the sole of the foot penetrated, with considerable bleeding, by accidentally stepping on the sharp point of a dry lilac-stock that had been cut off obliquely. What would be- 
IO5

come of wild horses if their feet were so vulnerable? How long would they escape the wolves?

I will say here, in passing, that when a horse has grown new and healthy hoofs, and. has been driven without shoes some time, if the bottom of the hoof is inspected, it will be noticed that the so-called bars which have been shaved out more or less completely, for the last hundred years, and for which practice the writers and teachers of the older veterinary colleges are chiefly, if not entirely, responsiblethese bars will be seen to have grown out to the level of the outer shell, and are nothing more nor less than the inner wall of the heels. The shell of each quarter, on reaching the back part of the hoofs, 
bends round at rather a sharp angle, and running forward and inward, gradually loses itself in the sole and forms with its fellow the triangular space in which the frog is developed. These bars have the same color as the outer shell, thus indicating continuity of structure. Between the bar and the outer shell the space is filled up with a greyish horny substance; at the sharp bend of the heel, firmly so, for a half inch or more, and as the space widens anteriorly, it is less densely packed, but pretty well filled up, giving a treading surface of more than an inch wide, a short distance in front of the angle. The loose packing of the larger part of the tread-surface would seem to prevent this surface from wearing smooth and becom- 
ing slippery; it certainly does preserve its roughness, and necessarily gives a secure hold upon the roadway, and with the assistance of the elastic frog, which fills up most of the triangular space formed by the bars, seems to effectually prevent any serious slipping.

Altogether each heel will have a ground surface averaging about an inch in breadth, by two or three in length, which gives perfect support to the foot, and much greater protection than any iron shoe can give, and note, that if these heels are seized and forcibly pushed apart, they will show a very perceptible yielding, thus giving considerable elasticity to the hoof, which must necessarily be restricted by a rigid shoe. 
Of course, I cannot go into this matter minutely - it properly belongs to the veterinary schools - but would call attention to these facts. If this is observed carefully by studying the hoof in the animal and not in the books, what I have pointed out can be verified by anyone.

At the risk of a little apparent repetition, I wish to refer a moment to the effect of dryness and humidity upon the hoof. It will be observed that as the hoof grows during the winter-that is, for the five months from the first of November to the first of the following April-the coarse, weak hoof that is grown in the closed stable during that time, gradually pushes down before it the portion of good hoof that was grown during the previous sum- 
mer-that is, in July, August, September and October - and in the spring - that is to say, in April, May and June - the wear will be entirely on this good portion of the hoof. But by about the first of July this part of the hoof will be worn out and the wear will begin on the weak winter growth, and this will continue during the rest of the summer and the following fall, and the difference in the strength of the two growths will be noticeable. This has given rise to the belief, which is very general, that the hot dry roads of this season of the year have caused the hoof to become weak and brittle, not perceiving that the animal is really wearing upon the weak growth of the previous winter, and its weakness and brittleness are owing 
to its having been grown in a closed stable, and not to the hot, dry roads. So, in the spring and early summer, when the hoof seems stronger and better, its condition is thought to be owing to the coolness and wetness of the roads. It is therefore a common belief that wetness and moist roads are good for a horse's feet, not understanding that at this time the strong portion of the hoof grown in the previous summer and early fall is bearing the strain.

Now, it must be apparent that dryness or wetness cannot be important factors as affecting the strength or condition of the hoof, else why is the hoof equally good in Ireland, where it is almost constantly wet and cool, and in Arabia, where it is almost 
constantly dry and hot? Anyone who has noticed the hoofs of dead horses lying in the fields, not only for months, but for years, without any perceptible change, must see that wet does not soften them or dryness make them friable, nor even freezing cause their disintregation. The hoof is not hygroscopic to any appreciable extent any more than a bull's horn. If it were otherwise, horses that are worked in water, or on muddy roads, for weeks at a time, as they constantly are, would be very soon disabled, and horses that traverse the hot and sandy deserts of Arabia would soon have nothing of the foot left but a friable, broken-up mass of crumbling hoof.

And thus we can see how futile must be 
the effect of poultices and wet applications and the various hoof ointments that are so much relied on to improve the texture and condition of the hoof. They simply produce the effect of a temporary varnish, improving, perhaps, its appearance, and thus deceiving the eye without affecting in any way its substance. By this I do not mean to ignore the sedative effects of water to the legs, or its cooling effect on the foot, in case the foot becomes from any cause heated or inflamed; but that wet applications to the hoof do not affect the hoof proper by softening or modifying it in any way, and whatever benefit may result from standing a horse with hot feet in water, for instance, comes from the contact of the water with the 


\section{I 3}

skin of the foot and leg, and from lowering the temperature of the foot by the conducting quality of the hoof, the hoof being capable of absorbing and transmitting heat, but not of absorbing water.

I know that a horse with hard frogs and heels - a constant condition, if the animal has been long and closely stabledwill, if turned out to pasture for a time, have the elasticity of the frog and heel restored, and this has been attributed to the dampness of the ground. But the same thing will happen in a stable if the air is constantly kept as fresh as in the pasture field, showing that the air is the causative factor, and not the ground.

Any change in the quality and texture 
of a hoof must be effected at the time of its growth at the matrix.

When a layer of hoof is formed, the work is completed so far as the active vital processes are concerned. These vital processes are active only within the hoof, in the sensitive parts, not in the outer insensitive parts - the hoof proper, as distinguished from the foot,- and the hoof becomes, and is, to all intents and purposes, an inorganic product. It is an effect of vitality, but has no vitality in itself, any more than a coral reef or an oyster shell. It has the properties of hardness, elasticity, toughness, and durability. It is insensitive, and resists decay or change, whether on the living animal or removed from the foot, and its removal 
makes no difference in these properties. You can paint it, as you could a bull's horn, and it would help or harm neither; it would only change the appearance. You can polish both, and engrave or ornament them at pleasure, and place them in a parlor, and they will remain unchanged for a lifetime.

It is as resistant to change as ivory or whalebone. Its quality depends on the condition of the blood of the animal at the time of its formation. As it was formed, so it remains, and it can only be modified by conditions that effect its nutrition as it is gradually being constructed. Physicians constantly see illustrations of this in the distortions of the nails occurring in phthisis and other constitutional 
diseases. No local applications to the nails are in the least curative. In some diseases these malformations of the nails can be remedied by internal medication acting on the nutritive processes, and by this means only - that is, through the blood.

And now, we can truthfully say, - "ex pede Herculem," - as the foot is, so is the horse. If, by securing and maintaining a perfectly healthy environment for our animal, we get perfect feet, all the other tissues of the body will share in the betterment, and the hoof becomes the result not only, but the index of that betterment.

But no one must suppose that a horse kept as I have described will go without shoes in a few weeks, or months. If used, 
he should be kept shod for about a year, because it takes that length of time to grow an entire hoof, and he must not be allowed to contract "thrush," and if he is suffering from thrush, it must be cured, or otherwise his frog will be tender, and he will not be able to go. Of course, no horse should be allowed to have thrush, as it is produced by standing on fermenting dung, or infected stable floors, and is evidently microbic in its nature. It is therefore easily preventable, and is cured by a number of microbicides, such as carbolic acid, sulphate of zinc, corrosive sublimate, etc. But perhaps the most convenient is dry calomel.

I have spoken of this more in detail than I otherwise would, even trench- 
ing a little on medication, which is rather the province of the veterinarian, and somewhat foreign to the general line of thought we have been pursuing, because thrush is among the few diseases that are not dependent upon the condition of the air, but is due to pollution of the stall.

Here let us observe, that the horse, one of the cleanliest and most fastidious of animals, does not seem to possess these traits when stabled. This plainly shows that he was never intended to be stabled. Nest-building or nest-hunting animals are always tidy about their sleeping places. Everybody must have observed that dogs never soil their beds, and this is true, in every instance, and of all such animals; even the hog, that was certainly never 
noted for his neatness, has this instinct. But the horse is entirely indifferent to and exercises no care in this matter at all. Why? Simply because a nest is foreign to his nature. When he urinates, however, he carefully extends his legs, to avoid having them spattered and soiled. He uses care here. But when you put him in a stable, and force him to sleep in a nest, contrary to his nature, his instincts not having been educated to the caring for, and keeping of a nest, are at fault, and necessarily so in an animal whose home is the open plain, and who seldom, or never, sleeps twice in the same spot, but finds a fresh place to rest whenever his needs require.

In whatever direction we look, whether 
we take into view his natural history, and study him in his wild state, or as we find him among savage or semi-civilized people, or, as he is under our own care, observing his habits and his instincts, and the diseases and disabilities to which he is subject, we cannot fail to recognize the fact that in his whole organization and development he is a free, wild, roaming child of the air and the uplands, without local habitation, gathering his food where it grows, seeking it wherever it may be found, and migrating from place to place, as suits his comfort and convenience. When we catch him and restrain him of his liberty, for our own use, and teach him to do our bidding, we must not restrain him of his right to breathe his native air, and 
we must also be careful to supplement his lack of the nest-keeping instinct by taking care of his nest for him.

These two things are essential to his well-being: clean air to breathe and a clean stall to stand in.

Here let us devote a little thought to one of the leading differences between typical fresh-air animals and those of the burrowing class. If any burrowing animal has endurance at speed it has not attracted attention. A rat cannot escape from a terrier except by regaining its hole. It cannot keep up any considerable speed, except for short distances; and the same is true of the domestic rabbit, the beaver, and also the bear; and I think this will be found true of all animals that seek 
close shelter; but the hare, or our common wild field rabbit, living always in the open, and depending as it does upon its speed for escape, will run miles, and test the strength of fleet dogs before it can be overtaken, in this respect closely resembling the horse or the deer. All of this class of animals that depend entirely upon speed for safety are typical out-door livers, and they seem to lay up and require a large reserve store of oxygen in the blood and tissues, which they cannot get unless constantly in the open air, and if this supply is restricted by forcing them to live in any degree like burrowing animals, they become to that extent degraded, and partly lose the peculiar chracteristics of their class, and while they may retain 
speed for short distances, they suffer loss in staying power and of endurance at speed, which is the crown and glory of the horse, and his birthright by nature. This indeed is just what we have been doing to the horse. We have taken from him the most valuable of his natural traits, by inanely forcing him to live like a rat in a hole.

If this is not true, why does nature keep her fast animals out doors?

Why does she give the instinct to keep in the fresh air, and avoid shelter, only to those animals which at the same time she teaches to run away from danger, and which alone, of all others, have the staying power to do so?

Has nature made any mistake here? 
Is this merely a matter of useless and unnecessary exposure, that she makes these fleet animals brave storm and cold without shelter, or is it not a plain case of cause and effect? Does it not clearly show that the one condition is essential to the other?

The same law seems to apply to birds as well as to their four-footed cousins.

Compare the soaring and circling of the hawk and the eagle, for hours together on the wing, but roosting on the loftiest crag or tree-top, with the rapid but comparatively short flight of the quail, the meadow-lark, or the partridge, which nestle in the grass or undergrowth.

Observe the swallow gliding on swift wing in endless rounds and complex gyrations, but building its nest in draughty 
chimneys where the air is constantly moving up or down with the changes of the weather, very different from the wabbling flight of the woodpecker that excavates a nest in a decaying tree for its home.

This appears to be a general law, that the capability of rapid and sustained movement in animals is dependent upon and in proportion to the amount of oxygen appropriated.

To care for the horse without antagonizing this law brings up for consideration the subject of stables.

It is not my intention to describe, minutely, how a stable should be built. The details of this must depend on varying and varied conditions. It should, however, be supplied with plenty of win- 
dows, but without any glass in the sash. Wire screening, of about one-eighth inch mesh is much better, as it lets in both light and air, and at the same time shuts out the larger flies and other insects, and protects the horse from annoyance by children and other thoughtless or malicious persons, and causes the air to come in slowly and steadily, without much blowing. There should be no shutters on these windows, as the stablemen are sure to shut them on cold or stormy nights and in wintry weather. I say this from personal experience, as I was obliged to have them removed from my stable for this very reason. They should be protected, however, by a hood, or some other contrivance, to keep out driving rain, or 
drifting snow-not that rain or snow would hurt the horse, for it would not; but is inconvenient and unpleasant for the attendants and owner. How this is to be done is a matter for the builder or architect to manage.

If, however, the air cannot be let in without admitting the snow, then let the snow come in. The air is essential, the snow merely a matter of inconvenience.

My stable has a ten-foot overhang on the north side, and most of the windows are on that side. Only one window on the east gives me any trouble at all in this way, but as the snow falls on the floor, in front of the manger, it is easily swept up, and gives me no concern.

The ventilators should be large, and 
arranged at the discretion of the builder. But they must be ventilators in fact, and not alone in name. They should have no closing valve, for they should remain open all the time. It should be remembered, however, that to maintain an air current, requires the expenditure of force, and this must be provided for in some way. In winter I find nothing better than an open grate fire in the stable-but this a larger experience has shown to be unnecessary, although often convenient,- - and in summer I have found that the sun's rays falling on the roof and front of the building can be utilized, and is sufficient to excite a satisfactory current, and is quite inexpensive. This, however, is a matter of mechanical detail. 
It must not be forgotten that a stable requires much more air than a dwellinghouse. Aside from the fact that a horse requires more fresh air than a man, from his original nature and constitution - not being an animal that in his wild condition seeks any shelter,- aside from this, I say, his habits differ very much from those of man.

As I have already said, he urinates in his stall, or box, and drops his dung where he stands, and this requires an extra allowance of air, to keep down unpleasant and unwholesome odors. What would be the condition of the air in a bedroom if man adopted the habits of the horse? And yet we have seen that, ordinarily, man supplies himself with a much larger 
amount of air than he gives his horse. Neither should we forget that the air of a close stable is a hot-bed of microbic forms. All kinds of pathogenic germs multiply here with great rapidity, and if the horse is injured by kicks, or other accidents, facilitating the entrance of germs, he will be liable to suffer from such diseases as tuberculosis and tetanus, especially the latter, which is common among horses, and as these diseases are now considered of microbic origin, his risks are increased by this exposure.

But aside from these comparatively rare forms, the pyogenic or pus-forming germs may be said to be omnipresent, and especially luxuriate, and multiply immensely, and take on increased virulence, in warm, 
foul, and quiet air. Whatever other germs may be absent, these are constantly present, and if an animal receives a wound, from any cause, they are always ready to settle upon the parts, and at once set up the festering process and the formation of pus or matter. If the injury is located directly over a bone, as in the shin or lower jaw, this process often extends to the periosteum - the membrane covering the bone and furnishing it its nourishment - and this frequently causes the death of a portion of the bone, and you have a long and tedious disease to care for, all because the animal has been forced to live in an atmosphere crowded with pus germs; or, if the animal takes cold and has in consequence a sore throat, 
these germs are very likely to effect a lodgment in the weakened mucous membrane and develop what the veterinarians call a quinsy, or strangles, or what-not; at any rate, pus is formed, and abscesses result, frequently breaking on the outside of the neck, slow to heal, and more or less dangerous to life. I have noticed that animals generally escape these complications if the air is kept sufficiently fresh; the wounds dry up, and "scab over," and as the inflammatory engorgement subsides, the scabs in a few weeks fall off, leaving a perfectly healed surface, without the formation of any pus whatever; and, indeed, this seems to be nature's method of cure in such cases.

In arranging the ventilation of a stable, 
it should always be kept in mind that the inside air can never, under any circumstances, be better or more healthful than the air outside, and you can have, at your own option, anything you aim at. With bad air go sickly and degenerate horses; with pretty good ventilation you will have pretty good horses; with good ventilation, good horses; but with perfect ventilation come perfect horses, - so far as individual possibilities admit-and the quality and condition of the hoof will follow exactly the same gradation.

Finally, the method of stabling we have been advocating commends itself to us, not only because it conserves the health and wellbeing of the animal, but also as a matter of convenience to the keeper. 
As there are no window-shutters to be opened and shut, they require no attention; the stable requires no airing in the morning, because it is always aired; and when being cleaned and swept, the dust is immediately carried out by the air currents, so as not to be annoying. But it should be distinctly understood and remembered, that the inorganic dust is much less harmful than the organic dust-those microscopic germs, before spoken of, which, though they cannot be seen, are potent for evil, "the invisible powers of the air," whose acquaintance we have formed only in recent years, which commit their depredations in the quiet, and on the sly, and which revel most where the air is most foul and most stagnant. 
As ordinarily kept, a horse must be taken out and exercised at stated periods, or he will suffer. But he may be absolutely confined to a thoroughly fresh stable without being taken out at all, especially if kept in a box, and he will suffer no harm. He will not gẹt stiff, his legs will not "stock," nor will he lose his appetite. He will remain perfectly well. I have seen this done so often, in the last four years, that I cannot be too positive about it. And this means a great deal in long storms and inclement weather of any kind. And in cases where horses are kept chiefly for pleasure, or are not in constant use for any reason, it is an immense saving of time, expense and trouble to get rid of the constant necessity for exer- 
cise. Whether a person's income be large or small, it is a great comfort not to be obliged either to exercise his horses himself or see that the exercise is not neglected by his groom, and know and feel that in this respect they are not suffering. Horsemen lay great stress on the importance of constant exercise, in keeping a horse in good condition. They have seen the benefit arising from this, so great and noticeable that the attention has been entirely fixed on the exercise, and they have quite ignored the oxygen in the fresh air, which was supplied by the outdoor work. Now, when we find the same benefit, from supplying the fresh air without the exercise, it must be seen that the exercise alone was not the chief cause 
of the bettered condition. Not that I would decry the value of exercise; this is good and valuable in its way - but its importance in preserving and restoring health has evidently been overrated. This principle once appreciated, we will be able also to see that the troublesome practice of swathing the legs with bandages and the body with clothing or wraps, is also quite unessential in a wholesome stable, and we will slowly become disenthralled from the control of our grooms not only, but also of our own vain imaginings, and learn to dispense with the artificial requirements, and perhaps necessities, of the unwholesome stable, by simply eliminating from the stable its element of unwholesomeness. To illustrate: I saw a 
horse-considerably out of condition at the time, with swelled legs among other things-put in a perfectly fresh stable during the month of November, I89I. That animal was taken out just three times, to my certain knowledge, from the time of entrance until the following April. I saw him driven several times in April, and he moved with the sprightliness and agility of a colt. This horse was taken to the country in May, and having been brought back to town in the fall, was kept the following winter in a close warm stable, and although not worked, was regularly exercised by the groom. He came out the next spring so stiff and spiritless that he would not have been recognized as the same animal; and although here- 
tofore always tractable and gentle, fell into the habit, when first put in this close stable, of breaking out of his stall and making an effort to escape. In this he finally succeeded, and running off, galloped to the fresh cold stable he had occupied the winter before, and entering, found his way, by a somewhat circuitous route, to his old box. Here he remained, quietly ruminating, and apparently happy, until he was found and taken away by his keeper. This may seem something like a fairy tale, but the facts, as stated, came under my personal observation. Here we may learn the important lesson, that the opinion a horse forms of the agreeableness of a fresh, freezing-cold stable is quite different from that of his keeper, and 
140

plainly shows the difference between the animal's unerring instinct and man's hobbling reason.

Again, on the other hand, while exercise has been credited with too much in maintaining a horse in good condition, it has likewise been unduly blamed for damaging the animal when excessive and exhausting. "Three blind 'uns and a bolter," which in the old coaching days in England was considered descriptive of the average stagecoach team, were not the product of the severe and straining work exacted of them, but of the stupidity of the stabling to which they were condemned after, and indeed before, their hard and tiresome drives. The prematurely old, distorted, stiff and wornout horses we 
constantly see-horses that are ruined and worthless at twelve, when they should be in their prime-owe their condition to the very same cause. Many of these horses can be restored, as I have seen, by placing them again in their natural habitat, clean, fresh air, but it takes too much time if the animal has been long and greatly disabled to be an economical procedure-except in extremely valuable animals - requiring two, or three or even four years to get the best results. Incipient or slight disabilities disappear in a few months.

To further illustrate this, I will say, that during the last four years I have seen a fine Kentucky saddle horse so stiffened in the shoulders by hard riding and 
close stabling that he had been condemned as perfectly worthless, and sold for a few dollars, after having undergone all the traditional treatment for that condition, for a long time without benefit. He was so disabled that he could hardly get in or out of the stable; he could not step backward with his left fore-foot at all, being obliged to drag it when moving, or trying to move, in that direction. This horse, kept as I have herein indicated, and without any other treatment whatever, in six months could be ridden with little show of lameness, in one year he moved nicely, and in eighteen months was practically well. For the first year he was almost constantly in his box, and only taken out at long intervals. For the 
first five months he was not taken out at all, and yet his improvement was constant and continuous. So these conditions, thoroughly maintained, conserve not only, but at the same time restore health.

Here a word of caution might not be out of place. If horses are kept in any stable for weeks or months without use they may contract thrush, especially if strange horses suffering from thrush are occasionally admitted. The disease is contagious, so the frogs should be constantly watched, whether the horse is shod or not, and any suspicion of thrush disposed of at once. How this can be done is suffciently stated on page I 7 .

Colonel Ingersoll is reported to have said, that "if he had made the world, he would 
have made health catching, instead of disease." That result to the horse will be realized if the conditions I have described are fully complied with, and the invaluable quality of endurance at speed, which by our common methods of stabling has nearly been lost, may again be restored to him, and instead of a feeble, sweating, weak-footed animal, we have once more a normal horse, perfect in health, in hoof, and in hardiness.

At the risk of seeming prolix, I will add here, that I have seen a young horse "over at the knees," with swelled hocks, and in bad condition generally, completely recover in a year by this method, and remain well, though subjected to constant hard usage, and that animal is still in per- 
fect condition; and another horse so disabled from what is commonly called "heaves," that it could scarcely be driven, completely cured in less than a year, and subsequently sold as a sound animal. Cases of so-called "sweeny," various eye diseases, etc., have disappeared without medication of any kind, under this method, and during the winter of I892-'93 - the coldest winter we have had for years, - out of a dozen horses so kept, not one had a cough or cold or suffered from sickness in any way. No horse was blanketed, and no horse shivered.

Here, objection will be made, that all this may be possible for horses slowly hardened to this extreme exposure to cold, but that those unaccumstomed to this 


\section{46}

method will suffer. Such, however, is not the case. During the past four years I have many times seen horses brought from close warm stables in midwinter, and placed at once, without any covering whatever, in a fresh cold one, and in not a single instance did they suffer in the least; no more than by turning them from a close warm stable into the pasture field, and this was never known to be hurtful. The accommodation is always complete and instantaneous, and the change immediately beneficial. I could not say this, and would scarcely have believed it, had I not seen it myself. The danger is not in complete freshness, but in partial, timid and incomplete freshness- the blowing of the wind through a small window, 
for instance, and striking the animal, in an otherwise tight enclosure. This might properly be called a draft, as differing from wind. Wind is air in perceptible motion. It may be fitful or irregular, and -is then called gusty, not drafty. A draft is wind restricted, so as to act locally and partially, not generally, and can only occur in an enclosure, as in the instance just mentioned. As soon as the motion is generally diffused, it partakes of the nature of wind, and is quite harmless not only, but agreeable and invigorating to the horse, because he is a windy-country animal.

The converse of the above proposition is, however, not true. The animal after having been kept in clean fresh air for a 
time cannot be transferred to a close stable, without great risk. He will almost certainly become sick, and often dangerously so.

In such a stable as we have described we have all the advantages of an open plain or pasture field, without the attending inconveniences and dangers. The animal is protected from snow, hail, rain and mud; the air and winds, though not excluded, are tempered by the screened windows. The horse is sheltered from the hot sun and the attacks of flies; he is in no danger of being injured by wire fences, or wounded or hurt by contests with strange horses; he cannot stray or be stolen or tampered with in any way; he is at hand to be cared for, and is always ready for use. 
We simply bring the air to the horse instead of turning the horse out to the air, and thus combine the freshness of the paddock with the safety of the stable, and this we have not for a few months, but during the entire year.

Strange to say,-no, not strange, but pitiful,-very many people close their stables as tight as possible; in the winter to shut out the cold, and in the summer to shut out the flies. They can feel the cold and see the flies, but the oxygen of the fresh air, being only visible to the mind's eye, they can neither see nor feel, and quite escapes attention. Thus in both cases the absolutely essential is excluded to avoid a merely trivial annoyance. How shall we rate the intelligence 
that can see a horse shivering in a close cold stable, and yet think he is more comfortable than in a fresh cold one where he never shivers, even after drinking ice water. Indeed, perfection in freshness is never reached short of this ice water test. Now this may seem incredible to many persons, especially to grooms and stable keepers, but it is not the less true on that account. It may be put down as a rule, without exception, unvarying and universal, that when a horse shivers from cold in a stable, it is because the air is not sufficiently fresh, and the remedy is not to close, but to open up freely, until all shivering ceases, and then forever afterwards keep up and maintain the same condition of freshness. No condition of the 


\section{5 I}

horse necessitates or justifies any modification of this rule. If sick, he needs no less air than if well; if tired and sweating no less than if fresh and dry. Closing the windows only puts him to a disadvantage, and so far from keeping him from catching cold, only renders him more likely to do so.

It is a noticeable fact, and one that I have repeatedly observed, that a horse turned out of his box or stall, in a perfectly fresh stable, and left to roam the stable at large, will not voluntarily leave the place, although the outside doors are left wide open; and if taken out and led away some distance and then turned loose, instead of racing through the streets, will, after a few preliminary 
jumps, turn about, gallop back, and reenter the stable.

I remember seeing a horse in February, I893, that had not been out for weeks, taken out, and the doors at both ends of the stable having been purposely closed, led up an alley perhaps two hundred yards to an intersecting street, and let go. After a few flourishes in the way of jumping and kicking, he ran back to the stable. Coming to the east door and finding it closed, he turned about and went to the west end, and this entrance being shut, he wheeled about again and entered on the carriage floor above, and went down the incline-van-way to his box. This is clearly because such horses are not suffering from air hun- 
ger, and know a good thing when they have it.

It will be found also that the behavior of a horse leaving a cool fresh stable on a cold morning is in marked contrast with the conduct of a horse leaving a close warm one. The former comes out quietly and sprightly, he sniffs the cold air but is not unduly excited by it; he seems to enjoy it without the least discomfort; while the latter is nervous, restless, excited, sometimes shivers, can hardly be kept quiet, and is difficult to control. Drive the first-mentioned horse five miles or so, and at the end of the drive he is just as fresh and free as at the startsometimes even more so. He sweats, if at all, very moderately, and is quite ready for 
another dash. The latter, after driving about the same distance, will lose spirit, toss his head up and down, as if fatigued, lop his ears, require the touch of the whip every little while to prevent his lagging, and move reluctantly, as "the whining school boy, creeping like snail unwillingly to school,"-and, instead of sweating on his neck, shoulders and flanks, as in the former case, will sweat profusely all over, and to such a degree as to have forced upon us the practice of clipping and singeing, as before mentioned. On stopping, it suggests the necessity of a blanket, which is never needed in the case of the first-mentioned horse, who can stop, after a drive in the cold air, with perfect impunity. I have 
seen my own horse, and he was a highstrung and nervous animal, stand an hour tied to a post at the curbstone, after a drive, when the thermometer was near zero, and instead of being restless and impatient, have found him quietly dozing.

The horse blanket then, instead of being, as many think, a positive necessity, is merely a matter of fancy-ornamental, perhaps, but quite unscientific-giving much more comfort to the owner than to the animal. Personally I never use one. This need not apply to stable wraps to keep the coat from being soiled or scratched, which is merely a matter of grooming. It will be noticed, however, that a horse will not rub himself, or tear his clothing in a perfectly fresh stable. 
It should not entirely escape our attention, that when we cover a horse with a blanket, no matter how much imaginary pleasure it may afford us, we are really only trying to protect the toughest part of the animal,- his roof, as it were, where the skin is the thickest, and the coat heaviest, and the sensibility the least,while the cold air has free access to the under parts of the body, where the skin is the thinnest, and the coat lightest, and the sensibility much the greatest.

There is another aspect of this subject, deserving more than a passing notice. After a horse has been kept for a year or two in his natural habitat, he regains all the certainty and accuracy of movement characteristic of the wild state. 


\section{57}

He never misses a step nor miscalculates a distance; all the original harmony existing between the special senses, the nervous system, and the muscular movements is again complete. $\mathrm{He}$ hears everything, sees everything, and is ready for every emergency. He will almost never stumble, and it seems impossible for him to fall. Instead of requiring to be guided and guarded from danger, he is himself conscious of every peril, and will avoid even those dangers of which his rider is not cognizant. His power and quickness of perception and readiness of resource are marvellous; all he requires is to be given the rein in difficult places, and he will bring himself and rider safely through every hazard. 
His eyes having elongated pupils, like those of the cat, he can see as well in a starless night as in the full blaze of the midday sun. Unlike man, blind in the dark, or the owl, blind in the sunlight, he requires neither a lantern at night nor a sunshade at noon, but can see with equal clearness in the dazzling glitter of sunlit snow fields, and in the, to us, pitch darkness of a cloudy midnight. He is thus a source of safety - a companion to be relied upon and trusted, instead of a machine to be guided. His rider may be dreaming or absorbed in thought, but he is always on the alert, watching over his master's safety as well as his own. His very existence in the wild state depends upon this vigilant quickness and ubiquity of 
vision. When wildly running over unaccustomed ground, in the night as well as by day, he must not tumble into ravines, or plunge into bogs, or collide with trees, or miss his footing, nor fall; if that should happen, it would settle for him the question of the survival of the fittest, and the prostrate horse would not be a candidate for preferment; his friends, the carnivora, would appropriate the remains, and leave the perpetuity of the equine race to animals that do not fall. Now with our domesticated horses nothing is more common than to see or hear of a rider goingdown with results more or less disastrous, because his horse has fallen, and this for the reason that his horse has lost the traits with which nature had en- 
160

dowed him, but which man has taken away.

It might be said, perhaps, that man's conduct towards the horse has not been very unlike that of the brooding hen, who, beguiled into hatching the eggs of a duck instead of her own, and not being familiar with the natural habits and instincts of her new acquisition, gives herself an endless amount of worry, because the little ducklings have such a reckless tendency to take to the water, and uses all her arts of pursuasion and cajolery to keep her wayward brood from being injured by this strange fascination. So with equal intelligence man has been indulging in anxious efforts to prevent the hardy, rollicking denizen of the 
windy plains, from being injured by the outside fresh air,- the one thing his instincts crave, and the demands of his nature make imperative.

The truth of it is, we have not heretofore been governed in these matters by reason, but rather by a sickly sentimentality and unknowledge. A horse cannot speak. He is incapable of expressing his wants, or feelings, in articulate language. If he could, he would indulge in a great deal of profanity, very likely. But to the observant he need not talk. When he pricks up his ears, and is quick and vigorous in his movements, his eyes bright, and eats with a relish, and does not shiver,-a horse always shivers if too cold-one may safely come to the con- 
ciusion that he is not unhappy. In forming an opinion as to his comfort, by thus interrogating the horse, we will be able to arrive at a rational conclusion; but if we form an opinion by consulting our own feelings or fancies, or the thermometer, we are sure to fall into error.

How, indeed, can we possibly tell as to what is agreeable to the horse, except by his appearance, conduct and actions? We can tell what is pleasant, or the reverse, to ourselves, by our own feelings, and we can infer from this as to the feelings of other men, but we cannot make any comparison between ourselves and the horse, because we belong to an entirely different class. We came into the world naked, with bare and tender feet, and we cannot 


\section{3}

run, or walk even, for years after birth. The colt is born with its coat on and a set of horn shoes to protect its feet, and can run, in a few hours, nearly as fast as its mother. We would not enjoy a mess of cut feed, nor take pleasure in masticating hay or grass, any more than a horse would be happy over a dinner of roast beef or ham and eggs. How, then, can we know that a horse delights in being kept warm, because this happens to be agreeable to ourselves? As soon as we begin to study this matter objectively, instead of subjectively, to learn to look, and see, and not merely to imagine, we will be approaching the line of modern scientific methods.

If what I have written is true, and it 
I64

is true, the greater part of veterinary medicine will have to be rewritten. All the diseases produced by the deficient oxidation of tissue must be eliminated, and aside from accidents, traumatisms, etc., very many horse diseases, now recognized, will go the way of "miliary fever" and such like afflictions of mankind that flourished two or three hundred years ago, when physicians shut their patients in close rooms, stuffed cotton in the key-holes, caulked the window and door cracks, sweltered the sick under loads of blankets, and gave hot drinks to sweat out disease, until at last it was found that fresh air and cleanliness had a value, and now even the names of these diseases are found only 


\section{65}

in medical text books of a century ago.

There was, of course, some excuse for these old doctors. Little was then known of the functions and philosophy of respiration, and even the existence of a pulmonary circulation had hardly been discovered, and was not at all understood. But this excuse is not available for us in the closing days of the nineteenth century, and it is a sad commentary on the intelligence of educated man, and we may add, of the medical profession, that in this regard we have retrograded instead of advancing; and in caring for our horses, we are practically behind the semi-civilized and even savage races.

Much intelligent care and study has 
been given to selection and breeding in the horse, and in this way many important traits have been developed or improved; but in great measure, often entirely, the fact that oxygen is as essential to his existence as food or water, has been ignored or forgotten. Deprived of food alone he will live many days, but will soon die if water is withheld, and almost at once if the supply of oxygen is cut off.

In this direction, I think, we must now look for any important advance in the future development or value of the horse. 



\section{7.}

andion

Nat :

ald

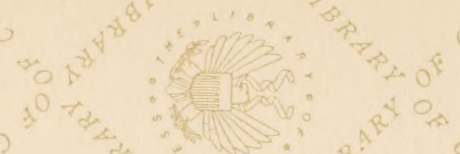

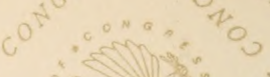

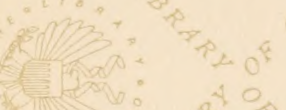

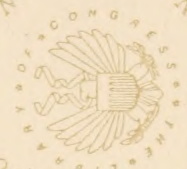

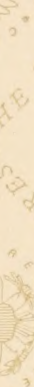

(n)

pte

o 


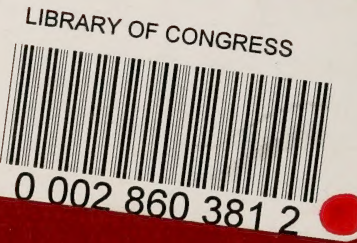

